\title{
Protocol for the design of quality bilingual education materials
}

\author{
María Elena Gómez Parra \& Barbara Muszynska \\ Universidad de Córdoba \& Lower Silesia University \\ elena.gomez@uco.es \& barbara.muszynska@dsw.edu.pl \\ https://dx.doi.org.10.12795/futhark.2019.il4.04
}

Fecha de recepción: 22.07.2019

Fecha de aceptación: 17.10.2019

\begin{abstract}
The objective of this study was to bring bilingual materials design into a research-oriented framework by using an innovative materials design protocol, to make claims about the effectiveness of the protocol itself as well as the quality of the materials based on the evidence collected after the study. This pilot study with a group of lower-secondary bilingual content teachers was conducted in Poland. The findings of our study showed the adequacy of the use of the materials design protocol. However, the prepared lesson materials seem to serve an informative and instructional purpose rather than experiential and exploratory, which would be more desired in the context of independent learning and bilingual education, hence, the need for the adaptation of the protocol with a greater focus on differentiation in bilingual education.
\end{abstract}

Keywords: Intercultural and bilingual education, materials design, ICT

\section{Protocolo para el diseño de materiales educativos bilingües de calidad}

Resumen: El objetivo de este estudio fue llevar el diseño de materiales bilingües hacia un marco orientado a la investigación mediante el uso de un protocolo innovador de diseño de materiales, que nos permiten contrastar la eficacia del protocolo, así como la calidad de los materiales, basadas en las pruebas recogidas después del estudio. Este estudio piloto se llevó a cabo con un grupo de profesores bilingües que impartían asignaturas de contenido de educación secundaria en Polonia. Los resultados de nuestro estudio mostraron la idoneidad del uso del protocolo de diseño de materiales. Sin embargo, los materiales de las lecciones preparadas parecían tener un propósito más informativo e instructivo que experimental y exploratorio, lo que parece más adecuado para un contexto de 
aprendizaje independiente y educación bilingüe; de ahí la necesidad de adaptar este protocolo prestando mayor atención a la diferenciación en educación bilingüe.

Palabras clave: Educación bilingüe e intercultural, diseño de materiales, TIC

Sumario: Introduction. I. Review of the literature. 2. Methods. 2.I. Gómez (2016) framework. 2.2. Piloting the new framework. 3. Findings. 4. Discussion

\section{Introduction}

This study addresses the concept of materials design in bilingual education from a holistic perspective using an innovative materials design protocol to help teachers plan their lessons more effectively. Materials development is claimed to be '. . both a field of study and a practical undertaking' (Tomlinson, 2017: 66). The need to develop and monitor materials is stated as an essential part of curriculum development in language teaching (Richards, 2017: 25I-252). The above shows that teachers' practical knowledge is crucial in curriculum/materials development (Golombek, 1998). Yet for it to be transferred into professional knowledge, it needs to be analyzed, verified, and improved, which this study aims to do.

In view of the above, and taking into account that there is little research on materials development, on the design and effects of materials produced by the teachers, we concluded that Gómez (2016) framework is an appropriate choice for the accomplishment of our goals for the following reasons. Firstly, Gómez (2016) had developed a methodological construct to help teachers plan, produce, evaluate and adapt their bilingual-intercultural materials for classroom settings, which, according to Tomlinson (2013), is an appropriate procedure. Secondly, Gómez (2016) had followed Mehisto's (20I2) criteria which, up to now, is one of the most renowned references for CLIL teachers' materials design and adapted them to meet these research goals.

Thus, the main objective of this study was twofold: first, to bring materials development into a research-oriented framework by using Gómez (2016) materials design protocol, so as to make claims about the effects of the protocol itself and the materials on the basis of the evidence collected during the study and to evaluate the effectiveness of both. We aimed to test the effectiveness of the above mentioned materials design protocol through its implementation with a group of 10 lower-secondary bilingual content teachers in Poland in the context of a bilingual education teacher seminar, where the participating teachers were asked to work in groups and prepare their lesson plans using our materials design protocol and to comment on its effectiveness in CLIL lesson planning sessions. The last stage was to 
evaluate the effectiveness of the protocol itself and contribute to it by remodeling it and preparing for the next study with teachers.

\section{Review of the literature}

The use of ICT is essential for the effective implementation of the Content and Language Integrated Learning (CLIL) approach as it makes learners feel more interested in what they are learning as they are engaged in the process of learning itself, and they discover and learn more when they are immersed within a collaborative learning process (Casado \& García, 2000). Marsh (2012: 36) declared that: 'Diversity in schools is not only related to the impact of migration, it is also linked to the inclusion into mainstream classes of young people with special or specific needs'. Several issues should be taken into account when planning ICTbased CLIL lessons for intercultural and diverse education. The use of ICT can provide stimulating visuals to support the scaffolding of languages, making it accessible for all students. The use of ICT can facilitate the production of attractive and professional resources for the lessons. However, the integration of ICT into the CLIL curriculum requires a considerable amount of time and planning, which is demanding, because of the lack of resources designed for specific CLIL purposes (Infante, Benvenuto, \& Lastrucci, 2009).

Therefore, teachers need specific training to embrace this new bilingual paradigm to teaching and learning (European Commission/EACEA/Eurydice, 2017), as well as appropriate classroom tools and materials that they can use while planning their lessons (Meyer, 20I0). Materials, following Tomlinson (20I3: 66): ‘... include anything which can be used to facilitate the learning of a language.' In the design of bilingual education materials, ICT is not only a tool for developing interactive strategies and ways that can contribute to foster independent learning but it can also be used for the design and creation of materials.

Thus, the justification of the choice for the methodological protocol established by Gómez (2016) comes from the fact that this protocol follows Mehisto's (2012) criteria for the design of teaching materials, where intercultural education and ICT are two of its fundamental criteria. Mehisto (2012: 26) speaks about ICT and general technologies as some of the requisites for the design and development of quality materials within bilingual education.

\section{Methods}


The methodological framework that our study describes the materials design protocol for CLIL lessons that can be used within intercultural and diverse bilingual education settings.

Here are the methodological steps that researchers herein have followed to accomplish the goals of this study: (a) Description of the methodological frame for the materials design (b) Lesson plans produced by a specific group of 10 bilingual lower-secondary history teachers (see Findings). (c) Evaluation of participating teachers on the methodological procedure carried out through a survey and an informal interview. A validated template was used, which queried participants on three key areas. This methodological procedure helped researchers discuss results (which has been centred on the adequacy of the use of a joint CLIL and ICT methodology materials design protocol for the learning of a second language through content within intercultural and diverse education), and establish the grounds for next stages of this work. Therefore, for the purposes of this study Gómez (2016) methodological protocol including ICT and intercultural and diverse education contexts is used.

A targeted group of lower secondary history teachers from Poland was asked to produce a series of lesson plans with the help of this methodological materials design protocol, which afterwards could be implemented in their daily lesson planning.

\section{I. Gómez (2016) framework}

Table I shows Gómez (2016) material design protocol. The protocol entails 3 inner stages, where a detailed description of the whole process is included to serve as a methodological guide for teachers (Stage 1: Previous actions. Stage 2: Design of ICT-based bilingual materials. Stage 3: Assessment). These three stages are thoroughly described, and each of these includes a section on: a. Specific actions to be carried out. b. A rationale that justifies the reasons behind such actions. c. Specific and contextualized examples for teachers who use these templates as a professional methodological guide.

\section{STAGE I. Previous Actions}

The first step herein is to help teachers set the scene by providing them with a complete array of the tools and actions they use for materials design, having in mind that the premise to be kept is ICT used within a bilingual context for intercultural and diverse education. 
Table I

STAGE 1: Previous Actions

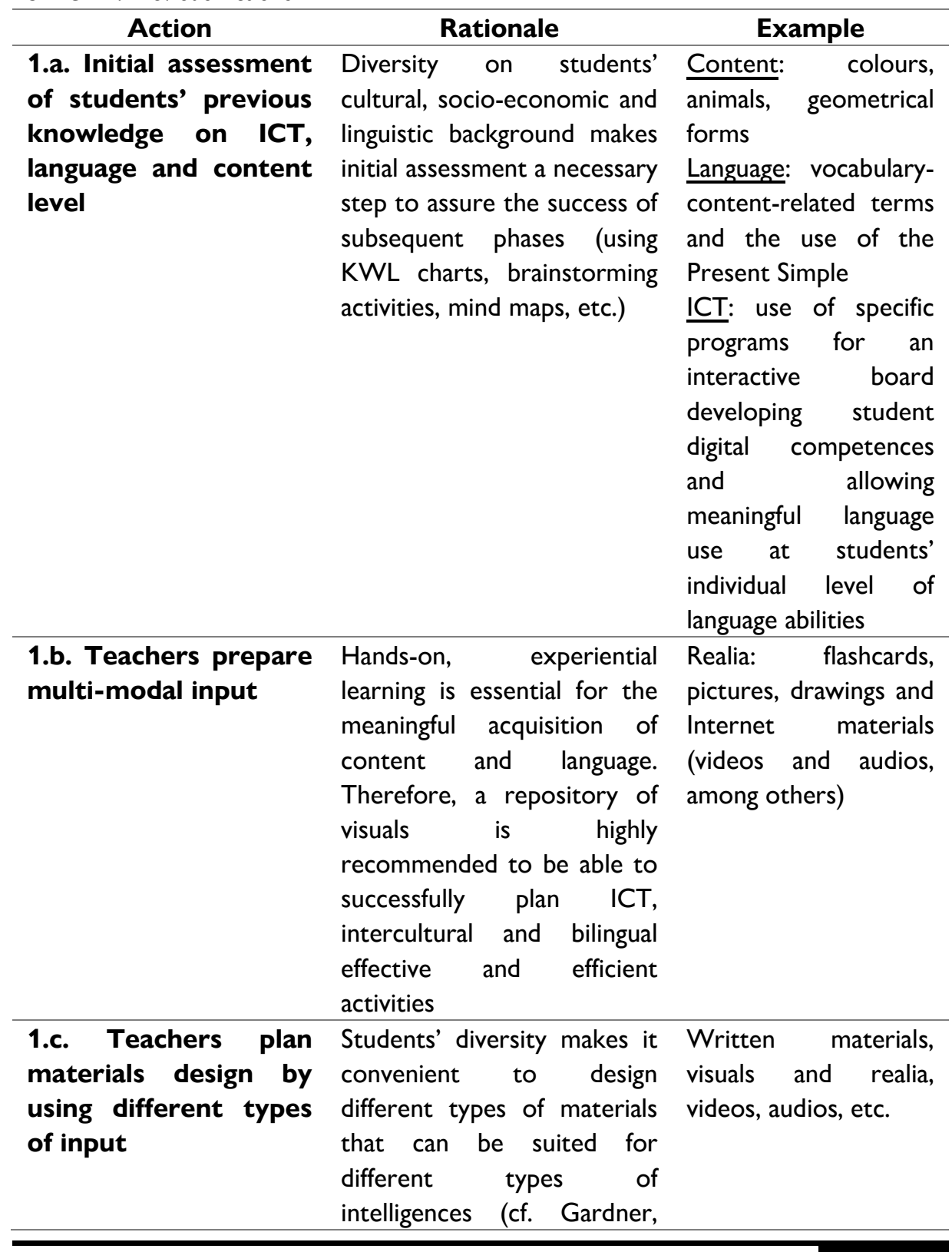




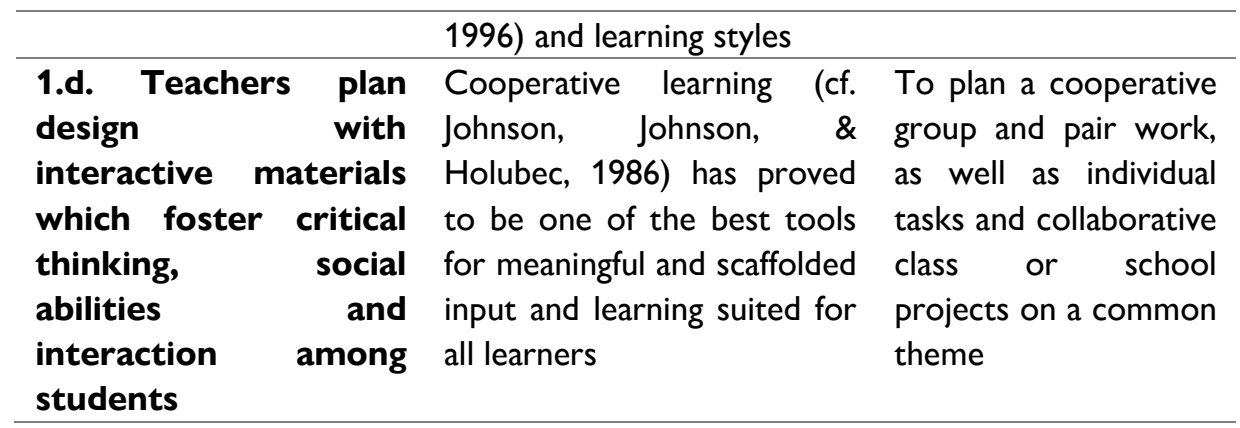

Source: own elaboration

STAGE 2: Assessment

The assessment of these activities is better accomplished by the use of checklists, which allow teachers to evaluate the students' performance during classwork. The specific criteria can be found in the Table 2 below. A joint-rubric design is set up here to account for the three areas: a. Language and content. $b$. Engagement on cooperative and collaborative tasks. c. ICT and intercultural competence. What is important to remember is that the assessment policies should provide opportunities for all students to demonstrate the achievement of learning outcomes.

Table 2

STAGE 2: Assessment

\begin{tabular}{|c|c|c|}
\hline Action & Rationale & Example \\
\hline $\begin{array}{l}\text { 2.a. Assessment of the } \\
\text { level of content and } \\
\text { language. For example: }\end{array}$ & $\begin{array}{l}\text { The design of the rubric } \\
\text { must allow teachers to } \\
\text { assess students through } \\
\text { observation in a }\end{array}$ & $\begin{array}{l}\text { 5-parameter rubric to } \\
\text { note down the students' } \\
\text { learning according to } \\
\text { course objectives and to }\end{array}$ \\
\hline $\begin{array}{l}\text { 2.a.1. Effective } \\
\text { processing of content } \\
\text { (showing understanding, }\end{array}$ & $\begin{array}{l}\text { formative way. The } \\
\text { parameters included in } \\
\text { the rubric must be easily }\end{array}$ & $\begin{array}{l}\text { each of the } 3 \text { areas } \\
\text { identified (content and } \\
\text { language; cooperative }\end{array}$ \\
\hline $\begin{array}{l}\text { negotiating, analysing) } \\
\text { using appropriate } \\
\text { content-obligatory }\end{array}$ & transferable to the grid & $\begin{array}{l}\text { and collaborative tasks; } \\
\text { intercultural and ICT } \\
\text { competence): }\end{array}$ \\
\hline $\begin{array}{l}\text { terminology (e.g. circle, } \\
\text { triangle, square) }\end{array}$ & & 1. Never ( 0 times) \\
\hline $\begin{array}{l}\text { 2.a.2. Effective } \\
\text { participation in a lesson }\end{array}$ & & $\begin{array}{l}\text { 2. Rarely (1-2 times) } \\
\text { 3. Sometimes (more }\end{array}$ \\
\hline
\end{tabular}




showing student
understanding and
reacting to and using
classroom/functional
language (e.g. please, sit
down, interactive board)
2.a.3. Content grammar
effective/communicative
use of passive
describing past events
2.b. Assessment of
students' level of
engagement on
cooperative and
collaborative tasks

of Once again, the design of of the rubric must allow on teachers to note down and easily their students' achievement on the engagement on activities. However this rubric should be filled in by the students themselves on the completion of a given activity as it refers to their inter and intrapersonal competences.

2.c. Assessment of Assessment here must students' level on their be really efficient to engagement on observe if students have intercultural and ICT improved their competence intercultural and ICT competence. The observation of this is more difficult as it is usually embedded (and shown) in other competencies (e.g. linguistic, social). than 3 times)

4. Frequently (5-6 times)

5. Always (more than 7 times or whenever s/he is asked) 
Examples of what can be
measured here in terms
of IC competence

(Secru, 2004):

- the ways in which culture affects language and communication (knowledge dimension),

- observation of students' understanding of otherness and acceptance of the difference

(skills/behaviours dimension),

- ability to evaluate critically perspectives, practices, and products in own and foreign cultures

(skills/behaviours dimension),

- positive disposition towards learning

(attitudes/traits dimension),

Examples of what can be measured here in terms of ICT competence:

- the ability to find things out; whether students are able to select the right source and assess the value of the information gathered,

- the ability to use ICT 


for different purposes,
e.g. to respond to
something, to plan
events, to record
information,
- the ability to share
information in real time
using, e.g. video
conferencing, or online
using a Wiki.

Source: own elaboration

\subsection{Piloting the new framework}

Since we aimed to test the effectiveness of the above-mentioned materials design protocol, the second step of our methodological procedure consisted of the implementation of Gómez (2016) protocol (as seen in section 2.I above) within a selected group of teachers. This was considered as a pilot study to the materials design protocol of this research. These teachers ( 1 male and 9 female) came from different cities across Poland and they voluntarily participated in a seminar on CLIL materials design that was delivered in Warsaw during the month of April 2016. The seminar involved three hours of lectures and discussions on bilingual education and materials design on one day and eight hours of workshops on designing materials, presentations of teachers' work and final discussions and evaluation on another day.

These were the common professional features of the cohort:

- They all worked at lower secondary bilingual education schools.

- They all taught one content subject (History) at bilingual school.

- Their second /working languages were either Spanish or English.

- Those teachers had between two to five teaching experience in bilingual schools.

The procedure of the seminar was as follows:

a. Firstly, the group of teachers attended a three-hour lecture on Content and Language Integrated Learning entitled 'The Fundamentals of CLIL", delivered by Gómez (2016). A discussion followed, whose main goal was to bring about and compare examples from their own everyday school practices. 
b. The second day consisted of a CLIL workshop, which was devoted to the discussion and analysis of the key theory on materials design within the specific context of CLIL and ICT (Gómez, 2016; Mehisto, 2012; Meyer, 2010; Coyle, 2007). At the beginning of this session, teachers have done Part I of the assessment survey Table 3 in this paper, as self-assessment and also analysis of their ICT skills and experiences, which helped to start the discussion and build on what they already were familiar with.

c. In the next part of the seminar, the teachers were asked to work in teams (two working groups were established; one for English as a second language, and the other one for Spanish). Then, each group had to produce 2 specific lesson plans in accordance with the materials design protocol presented herein. Moreover, one of the main aims for the teachers was to use ICT for material design.

d. Participating teachers developed their plans collaborating in their groups. Then, they shared their work, so they had the opportunity to comment on their peer lessons' design.

e. Finally, teachers agreed that their work could be displayed online in order to share the lesson plans with other lower-secondary History teachers.

f. Teachers agreed to take surveys as the evaluation of the seminar. There were also informal interviews conducted at the end of the last session.

The two teams produced two lesson plans each:

Team I used English as their second language and produced the following two lesson plans:

Lesson I: Christopher Columbus - the accidental hero.

Lesson 2: Education in Ancient Sparta and Ancient Athens - comparison.

Team 2 used Spanish as their second language to produce these lesson plans:

Lesson I: Los Juegos Olímpicos antiguos y modernos.

Lesson 2: Comparación de la arquitectura de la Catedral de Santiago de Compostela y la Mezquita de Córdoba.

\section{Findings}

After the seminar, the teachers declared to have found this practical approach to materials design valuable for their teaching practice, as it provided a safety-net for them. However, since it was the first time they used a certain 
materials design protocol to plan lessons, they struggled with a few specific procedures within the lesson design. They have also admitted that as much as cultural and intercultural aspects of their content subject is well-known to them and obvious to incorporate within a lesson, they still struggle with the lesson design for the diverse education in terms of students' special needs and would need more guidance in this respect. The teachers have also said that in a typical lesson they have no time to hand the assessment over to the students as it is too timeconsuming and they prefer to set homework and assess it later on. The quantitative results in a form of surveys were collected from the teachers after the seminar (Sections 2 and 3, Table 3). The qualitative results were collected in the form of informal interviews with the teachers after the surveys were conducted. The surveys followed a template which had been previously validated according to a Delphi method, where an international panel of eight experts on CLIL, teaching methodology, ICT, and intercultural education (two from each field) provided their judgements on the relevance and appropriateness of the questions proposed. The template was divided into three areas: Section I. Their past teaching practices on materials design, up to the moment. Section 2. The quality of the seminar and its usefulness and fulfilment of the objectives - planning a lesson with a materials design protocol (Gómez, 2016). Section 3. The foreseen usefulness of the procedure learnt along the course for their actual and future bilingual classroom settings. The measurement was carried out through a I-4 Likert scale, where I meant 'little' and 4 meant 'a lot'. Additionally, a section for 'additional comments' was added, so that researchers could collect the teachers' additional opinions stated during the informal interviews.

A summary of the answers trainees provided can be seen in Table 3 below:

Table 3

Summary results of teachers' opinions

$\begin{array}{ccccc}1 & 2 & 3 & 4 & \begin{array}{c}\text { Additi } \\ \text { onal } \\ \text { Comm } \\ \text { ents }\end{array} \\ \end{array}$

Section 1 (done before the lesson planning part)

$\begin{aligned} & \text { A. Have you } 87.5 \% \\ & \text { designed }\end{aligned} \begin{aligned} & \text { 12.5\% } \\ & \text { ICT }\end{aligned}$
$\begin{aligned} & \text { materials for your } \\ & \text { bilingual lessons } \\ & \text { before this seminar? }\end{aligned}$




\begin{tabular}{|c|c|c|c|c|}
\hline $\begin{array}{l}\text { B. Have you } \\
\text { designed any type of } \\
\text { materials especially } \\
\text { for intercultural and } \\
\text { diverse education } \\
\text { contexts in your } \\
\text { bilingual courses } \\
\text { before this seminar? }\end{array}$ & $50 \%$ & $12.5 \%$ & $12.5 \%$ & - \\
\hline $\begin{array}{l}\text { C. Have you } \\
\text { designed any type of } \\
\text { materials for your } \\
\text { bilingual courses } \\
\text { before doing this } \\
\text { course? }\end{array}$ & $87.5 \%$ & $22.5 \%$ & - & - \\
\hline
\end{tabular}

Section 2 (done after the lesson planning part)

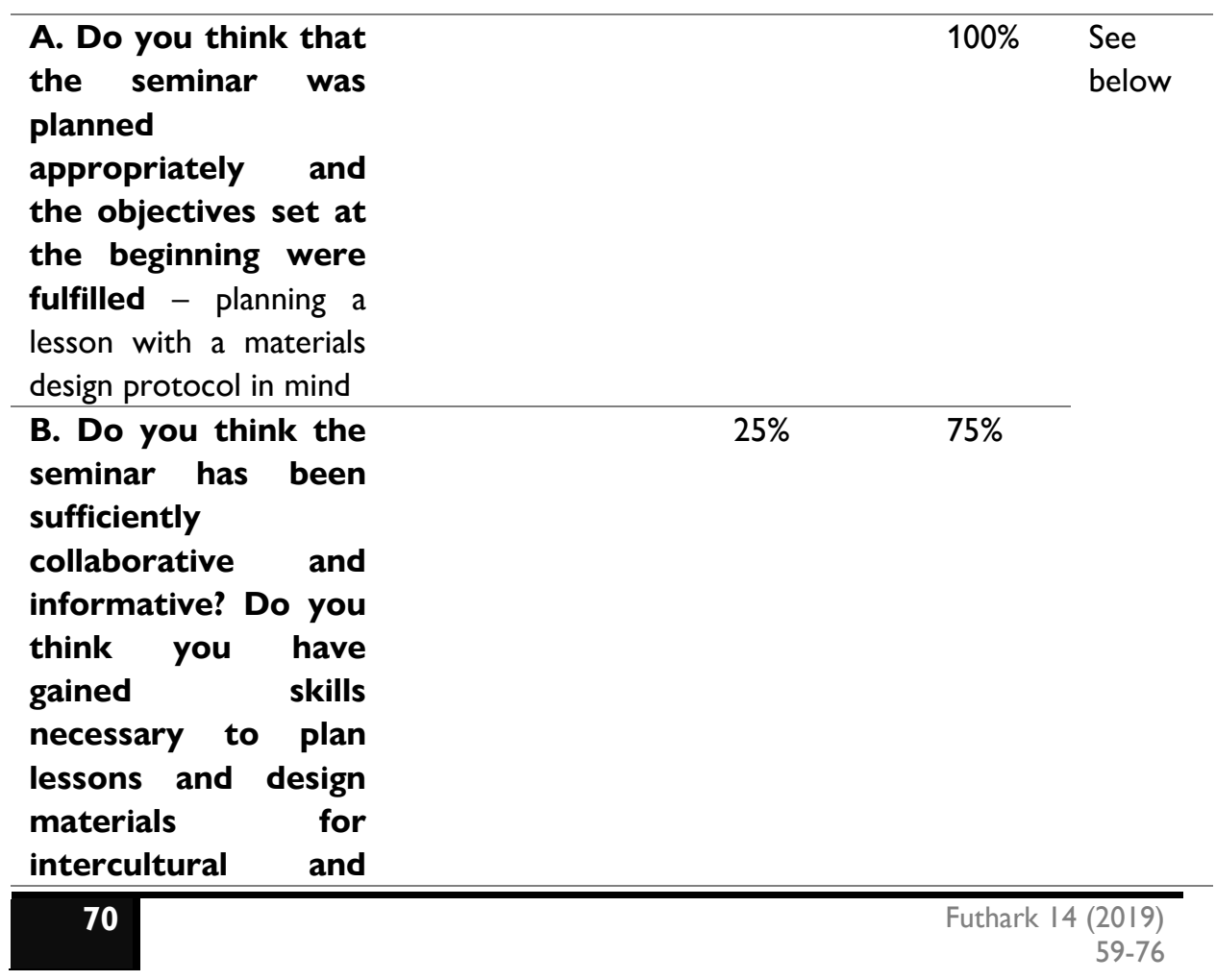




\section{diverse education}

using ICT?

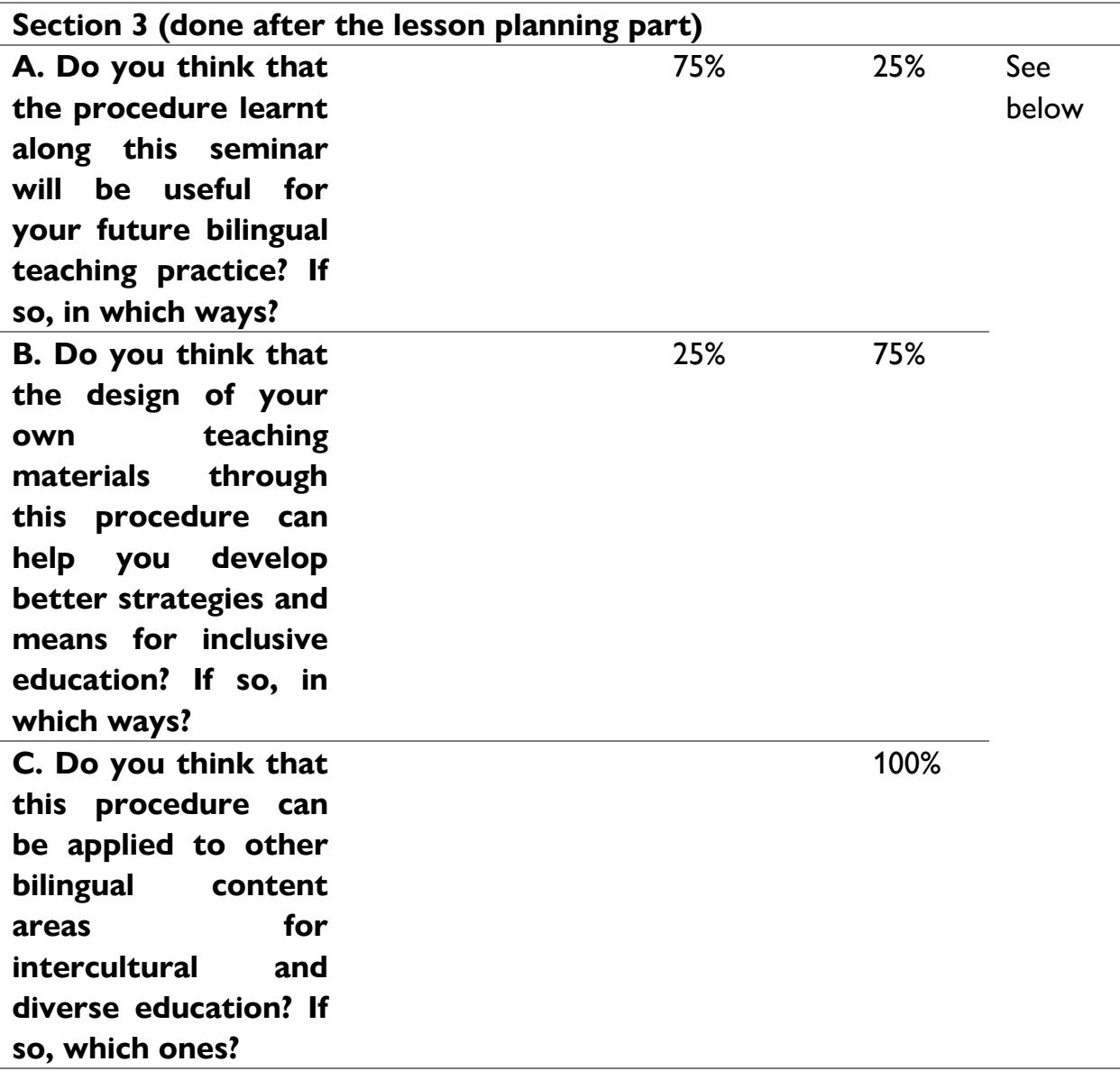

Source: own elaboration

Most participating teachers stated that generally, they do not use one typical lesson structure during the school year, as there is very little time to produce full lesson plans. The majority of them also commented, however, that the methodological frame they used along the seminar was helpful and assisted them to design the lessons more effectively. All of the teachers included some activities that 
activate students' previous knowledge and personalise or individualise student learning. Activities fostering previous knowledge mostly found their place at the beginning of the lesson as a brainstorming activity with the use of a mind map. Here's an example from the Lesson I: Christopher Columbus - the accidental hero (Lesson Plan I - Team I):

\section{Etap 2. Task 1}

1. Students read the text and learn the content vocabulary (appendix 1).

2. Students match the words with their definitions.

\section{Etap3. Task 2}

1. Discussion and brainstorming based on the warming up mind map. We travel in time and move back to the 15th century (to year 1492). Students provide the information basing on the text and their knowledge of the times of the early explorers.

2. Make the list of similarities and differences (now and then).

3. Closing up discussion. Watch the short film and while watching think about the answers to the questions:

Why some Americans may not want to celebrate the Columbus Day? What might be the reasons?

https://www.youtube.com/watch?v=GXqqdjJN6nU

Etap 4. Homework

1. Students' own research. Complete the table with missing information.

\begin{tabular}{|l|l|l|l|l|l|l|}
\hline explorer & nationality & destination & time & $\begin{array}{l}\text { discovered } \\
\text { territnries }\end{array}$ & $\begin{array}{l}\text { colour on the } \\
\text { rnute nn the }\end{array}$
\end{tabular}

What is visible is that the above group included a discussion and comparison of the old and present time. It does not say however what do students do with a list of similarities or differences. The discussion leads to a video linked to the American culture, which is in line with our methodological materials design protocol. The lesson is $\mathbf{4 5}$ minutes long, and this group of teachers explained that there would be little time to include more in it. The assessment is done as homework in this instance (students get to choose which explorer to write about, but the Table is solely factual). The last question 'Why might some Americans want to celebrate Columbus Day? checks the understanding of the main topic of this lesson (content and language) as well as cultural sensitivity. The lesson can also be formatively assessed based on the collaborative task of a mind map and students' 
ideas and language, as well as through the observation of the level of student engagement and relevance of points mentioned in the final discussion. All this is in accordance with our methodological materials design protocol.

Regarding ICT, majority of the teachers decided to use video clips to design classroom materials as seen in the example above, which shows that the modern media are used to present students with content, but this does not develop their digital competences as such.

One of the groups included an activity based on creating student own podcast in their lesson plan (Task 2 below). An example from Lesson 2: Education in Ancient Sparta and Ancient Athens - comparison (Lesson Plan 2 - Team 2):

1. We divide the class into two groups (by counting to two or drawing lots).

2. We inform the students that they are going to watch the visual materials (the video $/ 1 \mathrm{~min}$ / and the painting).

Basing on the visual aids students fill in the content table (appendix 1).

What were the students like?

Name their features of character and behaviour.

3. Read the text and write down the main objectives of the educational system (appendix 2).

Justify the claim that the features and behaviour listed in task 1 were necessary to achieve success at school.

Etap 3. Task 2.

1. Prepare a radio programme about everyday life in a school in ancient Sparta or Athens. The interview must be taken from different perspectives: parents, teachers, students). Construct your programme to highlight the main objectives of the given educational systems.

2. Groups listen to the podcasts (or watch the dialogues) and make the list of the objectives.

3. Students discuss their findings and complete the table (appendix 1).

Etap 4. Closing up

Why didn't girls appear in the visual material?

As seen above in Task 2, students are asked to use the information they have from the text in Task I no. 3 to create a podcast using a perspective of a parent, teacher or a student. This setup enhances higher-order thinking skills, improves collaboration, authentic communication and dialogue among students, personalizes and individualizes the task by making it more accessible for students 
with different needs and backgrounds (inclusive education). Students need to agree and disagree on how to organize their work and complete the task. The last activity can be a foundation for a wider discussion on human rights and democracy in the modern (inclusive) world.

It can be assumed from the observation that the teachers decided to use new media tools they were familiar with as they wanted to focus more on the materials design protocol, which was new to them. They all declared that in the future they would try to use different ICT tools as well as ways of implementing them in the classroom.

Regarding the usefulness and fulfilment of the objectives of the seminar planning a lesson with a materials design protocol in mind (Gómez, 2016), most of the teachers agreed that it was of high value to them and that it had been carefully and purposefully planned. Some of them highlighted the fact that they would like to continue training in this way and suggested the use of more cooperative learning techniques and ICT within these type of courses. Finally, the third section of our survey was focused on the foreseen use of the procedure learnt. Most of the teachers agreed that this technique would be useful for their future bilingual practices.

\section{Discussion}

The informal interviews carried out revealed that teachers understand the advantages of using a formal and standard procedure to develop their ICT and bilingual materials/lessons. Although, as shown above, this aim has only partially been achieved.

The main limitation of this study can be identified by the number of participating teachers in our research. Nowadays, it is quite difficult to get universal access to bilingual schools because they are overloaded with daily work and with research carried out by institutions. Therefore, though we must be cautious with the results and conclusions herein stated, we believe that the information gathered can be useful to develop further and more complex analyses in this line.

In the work produced by this group of teachers, there is some space used for collaborative work and active learning, but too little place was devoted to personalisation and individualization of learning or inquiry, students making their own decisions about learning, which are essential components of inclusive education. Despite the declaration of the participating teachers identifying the relevance of the procedure for their work, the prepared lesson materials seem to serve a more informative and instructional purpose rather than experiential and exploratory, which could foster communication, cooperation, independent learning 
and diversity. What can be observed, is that teachers focus more on their teaching than on their students' learning when they plan and design their lessons, which also leaves us with room for improvement of our methodological materials design protocol in this respect. We also believe that the next step should be to plan a full module of study, not a single lesson, as it would allow us to fully examine our materials design protocol and to make further improvements to it.

\section{References}

Casado, J., \& García, M. 2000. 'Consideraciones didácticas sobre la enseñanza de lenguas.' Didáctica (Lengua y Literatura), 12: 67-89.

Coyle, D. 2007. 'Content and Language Integrated Learning: Towards a connected agenda for CLIL pedagogies'. International Journal of Bilingual Education and Bilingualism, 10/5: 543-562.

European Commission/EACEA/Eurydice. 2017. 'Key Data on Teaching Languages at School in Europe - 2017 Edition'. Eurydice Report. Luxembourg: Publications Office of the European Union.

Gardner, H., Kornhaber, M. L., \& Wake, W. K. 1996. 'Multiple Intelligences.' Fort Worth: Harcourt Brace College Publishers.

Golombek, P. 1998. 'A study of language teachers' personal practical knowledge.' In TESOL Quarterly, 32/3: 447-464. Available at https://doi.org//0.2307/3588II7 (accessed on 15 April 2018).

Gómez, M.E. 2016. 'Diseño de materiales bilingües e interculturales en educación infantil.' In $M^{\mathrm{a}}$ I. Amor Almedina, J. L. Luengo-Almena \& M. Martínez Atienza (eds.), Educación Intercultural: metodología de aprendizaje en contextos bilingües. Granada: Atrio. pp. 39-48.

Infante, D., Benvenuto, G., \& Lastrucci, E. 2009. 'The Effects of CLIL from the Perspective of Experienced Teachers.' In D. Marsh, P. Mehisto, D. Wolff, R. Aliaga, T. Asikainen, M. J. Frijols-Martín, S. Hughes, G. Lange \& A. Di Cura (eds.), CLIL Practice: Perspectives from the Field. Jyväskylä, Finland: University of Jyväskylä. pp. I56-163

Johnson, D. W., Johnson, R. T., \& Holubec, E. J. 1986. 'Circles of learning: Cooperation in the classroom.' Edina, MN: Interaction Book Company.

Marsh, D. 2012. 'Content and Language Integrated Learning (CLIL): A Development Trajectory.' Córdoba: Universidad de Córdoba. Available at http://bit.ly/2x2RdDN (accessed on 28 March 20I8).

Mehisto, P. 20I2. 'Criteria for producing CLIL learning material.' Encuentro, 2 I: I533.

Meyer, O. 2010. 'Towards quality-CLIL: successful planning and teaching strategies.' Puls, 33: II-29. 
Murphy, C. 2006. 'The impact of ICT on primary science.' In P. Warwick, E. Wilson \& M. Winterbottom (eds.), Teaching and Learning Primary Science with ICT Berkshire, England: Open University Press. pp. 13-32.

Richards, J. C. 2017. '50 Tips for Teacher Development.' Cambridge: Cambridge University Press.

Tomlinson, B. 2013. 'Materials development.' In R. Carter \& D. Nunan (eds.), Teaching English to Speakers of Other Languages Cambridge: Cambridge University Press. Pp. 66-7I.

UNESCO 2005. 'Guidelines for inclusion: Ensuring Access to Education for All.' Paris: UNESCO. Available at http://unesco.org/educacion/inclusive (accessed on 10 May 2018). 